\title{
SELECTION OF HEATING SYSTEM BASED ON ACQUISITION AND OPERATING COSTS FOR FAMILY HOUSES
}

\author{
Miloslav Novotný1, Karel Šuhajda ${ }^{2}$, Radim Kučera ${ }^{3}$, Eva Šuhajdová ${ }^{4}$ \\ Department of Building Structures, Faculty of Civil Engineering, Brno University of Technology, \\ Veveř́ 95, 60200 Brno, Czech Republic \\ E-mails: ${ }^{1}$ novotny.m@fce.vutbr.cz; ${ }^{2}$ suhajda.k@fce.vutbr.cz (corresponding author); \\ ${ }^{3}$ kucera.r@fce.vutbr.cz; ${ }^{4}$ suhajdova.e@fce.vutbr.cz
}

\begin{abstract}
The aim of this study is to evaluate mutual dependences and significance of the input factors of a heating system for a family house. The input factors which are being most commonly considered are operating costs, acquisition prices on financial return rate, life span of these systems or requirements for maintenance and control. This research is focused on the analysis of three different heating systems in the common detached house; electric heating foils, heat pump and gas boiler. The building itself is evaluated in three variants; with and without a ventilation unit and with adjusted structure composition. To analyse the parameters mentioned above the Promethee method (multicriterial analysis) has been used.
\end{abstract}

Keywords: heating, return rate, price for energy, heat loss, multi-criteria analysis, PROMETHEE.

JEL Classification: P18; C38; Y80.

\section{Introduction}

One of the most important decisions the building owner has to make when creating a project of either the newly constructed building or the one which is to be renovated is the selection of the heating system.

When choosing a heating system, it is necessary to take into account a number of input factors; a type of building, use of building, climatic conditions, availability of sources, price of individual energy sources, acquisition costs, investor's requirements, and many others (Rajagopalan et al. 2012).

This article focuses on the analysis of the most commonly used heating systems based on the price of energy and acquisition price for individual types of heating. Other input factors are already included in the type and location of the building.

The comparison includes three most commonly used heating systems (Najbrt, Lenoch 2012). They are electric heating foils, heat pump air/water, and gas boiler. The comparison deliberately excluded heating by wood due to its more specific use.

The aim of the evaluation is to determine which of the input parameters, acquisition price and price of energy in relation to the system life span, has a greater influence on the price return rate, which is achieved by multicriterial analysis.

\section{Building description}

The building, whose evaluation was performed, is located in Central Europe, in the village of Vřesiny, Moravia-Silesia region, the Czech Republic. It is a single floor wooden family house designed for four people. The house is designed for a barrier-free use (ČSN 734301 2004). The house has a rectangular layout. The living quarters of the building amount to $172.14 \mathrm{~m}^{2}$. Most of the residential parts of the building are oriented to south, where large glass areas are located as well. The roof on the southern side overhangs in order to prevent overheating of the building. (Kolb 2011) Wooden windows Alphawin with the frame heat transfer coefficient $\mathrm{Uf}=0.79 \mathrm{~W} /\left(\mathrm{m}^{2} \mathrm{~K}\right)$ and the insulated triple glazing heat transfer coefficient $\mathrm{Ug}=0.50 \mathrm{~W} /\left(\mathrm{m}^{2} \mathrm{~K}\right)$, solar factor $g=0.54$ were selected for the building. The solar glazing $\mathrm{Ug}=0.60 \mathrm{~W} /\left(\mathrm{m}^{2} \mathrm{~K}\right), \mathrm{g}=0.63$ is installed on the southern side (ČSN 73 0540-4 2005). Exterior surfaces of the building are considered in two variants with different heat transfer coefficients $U$, see Table 1 . In order to show a more illustrative evaluation of the given issue, the building is equipped with an air handling unit system (AHU) with general effectiveness of $75 \%$ (Kulhánek 2010; Hirvonen et al. 2016).

Regarding construction, it is a wooden building built in the two by four system. The building is built

(C) 2016 The Authors. Published by VGTU Press. This is an open-access article distributed under the terms of the Creative Commons Attribution License (CC-BY 4.0), which permits unrestricted use, distribution, and reproduction in any medium, provided the original author and source are credited. 
on reinforced concrete foundations. A flat green roof was designed for the building. The heat insulation mainly includes soft fibre insulation of different types, based on the evaluated variants. The insulation, $160 \mathrm{~mm}$ thick, is placed in between the posts, a rigid insulation fibreboard, $120 \mathrm{~mm}$ thick, in front of the posts and insulation of $40 \mathrm{~mm}$ in the installation gap from the inner side (Kolb 2011). Expanded polystyrene, whose thickness and type varies by variants, is used for floors and the roof (Bečkovský et al. 2012). Three variants were evaluated. Variant I - the existing condition of the building. Variant II - original condition of the building with an air handling unit and Variant III with an air handling unit and with the use of more effective heat insulation of a greater thickness (Table 1).

Table 1. Variants of construction of building envelope used for evaluation (Source: ČSN 73 0540-2 2011)

\begin{tabular}{c|c|c|c}
\hline Variants & I. & II. & III. \\
\hline Construction & \multicolumn{3}{|c}{$\mathrm{U} \mathrm{W} /\left(\mathrm{m}^{2} . \mathrm{K}\right)$} \\
\hline Wall & \multicolumn{2}{|c|}{0.140} & 0.132 \\
\hline Roof & \multicolumn{2}{|c|}{0.273} & 0.152 \\
\hline Floor & \multicolumn{2}{|c|}{0.145} & 0.129 \\
\hline
\end{tabular}

\section{Energy evaluation of the building}

The building was evaluated in software PHPP CZ V8.5. The evaluation includes heat losses of the building by heat transfer and ventilation, solar gains for the given locality, and internal heat gains from appliances and people. In order to simplify, thermal links were omitted in the calculation (Yildiz, Güngör 2009). The climatic data for the given area were taken from software PHPP CZ V8.5 (Feist 2013), the design temperature of exterior $-14.2{ }^{\circ} \mathrm{C}$ and $-13.2{ }^{\circ} \mathrm{C}$ (ČSN 73 0540-3 2005). The designed internal temperature was set to $20{ }^{\circ} \mathrm{C}$. The consumed energy for heating of the building in the designed variant is summarized in Table 2 (ČSN 73 0540-1 2011).

Table 2. Energy evaluation of the building by variants, output from PHPP CZ V8 5 (Souce: Feist 2013)

\begin{tabular}{l|c|c|c|c}
\hline \multicolumn{5}{c}{ Input data } \\
\hline & I. & II. & III. & \\
\hline A & 5.93 & 4.46 & 4.00 & $\mathrm{~kW}$ \\
\hline B & 40.70 & 22.60 & 15.90 & $\mathrm{kWh} /(\mathrm{m} 2 \mathrm{a})$ \\
\hline C & \multicolumn{5}{c}{172.14} & $\mathrm{~m} 2$ \\
\hline D & 7006.10 & 3890.36 & 2737.03 & $\mathrm{kWh} / \mathrm{a}$ \\
\hline A - Heating performance \\
B - Specific amount of heat for heating \\
C - Flooring area \\
D - Consumed energy per year \\
\hline
\end{tabular}

\section{Selection of heating system}

The evaluation of heating systems included electric heating foils (Fenix 2015), heat pump air/water, and gas boiler. These systems were selected for the differences in the systems, their popularity, great difference in acquisition costs, and difference in energy carriers. The acquisition costs included all main elements of individual heating systems, so that the most frequently used systems were found. The individual heating systems and a summary of advantages and drawbacks are shown below (Kazanci et al. 2016; Debacker et al. 2013).

Electric heating foils:

- Contains its own heat distribution.

- No mechanical parts, longer life span.

- Easy regulation.

- Acquisition price.

- No maintenance.

- Higher operating costs.

- No change of heat source (in the future).

- No subsidies without using a renewable source.

Heat pump air/water:

- Low operating costs.

- Cheaper tariff for electric energy for operation of the building.

- No maintenance operation.

- High acquisition costs.

- Limited life span of compressor (max. 1520 years).

- Necessary to install heat distribution channels.

- Necessary to complement with a bivalent source of heat.

Gas condensing boiler:

- Effective use of a (non-renewable) source.

- Cheaper operation.

- Need to build a chimney and gas fixtures.

- Boiler life span.

- Necessary to install heat distribution channels.

- Higher acquisition price.

- Maintenance necessary.

\section{Acquisition price and used tariffs}

The acquisition prices of individual heating systems included the basic elements which are used for the operation of the system. The selected heat sources are dimensioned for the given building. The prices include VAT effective at the time of evaluation. The acquisition prices are shown in Table 3-5. 
The variants II and III used air handling units in the basic design with the price of $€ 1500$.

Table 3. Acquisition price: Electric floor heating ECOFILM (Source: compiled by the authors)

\begin{tabular}{l|c|c}
\hline \multicolumn{3}{|c}{ Electric floor heating ECOFILM } \\
\hline Component & amount & price $[€]$ \\
\hline $\begin{array}{l}\text { Heating foils Ecofilm F 608/55, } \\
\text { 44 W/m }\end{array}$ & $185 \mathrm{~m}$ & 2021 \\
\hline Central regulator BMR RT09 & $1 \mathrm{pc}$ & 690 \\
\hline Control unit BMR HC 64 & $1 \mathrm{pc}$ & 268 \\
\hline Room thermostats & $6 \mathrm{pcs}$ & 82 \\
\hline Total & \multicolumn{3}{|c}{3062} \\
\hline
\end{tabular}

Table 4. Acquisition price: heat pump air/water (Source: compiled by the authors)

\begin{tabular}{l|c|c}
\hline \multicolumn{3}{c}{ Heat pump air/water } \\
\hline Component & amount & price $[€]$ \\
\hline Heat pump air/water & $1 \mathrm{pc}$ & 5481 \\
\hline Internal unit & $1 \mathrm{pc}$ & 3593 \\
\hline Floor heating distribution & $160 \mathrm{~m}^{2}$ & 6281 \\
\hline Total & \multicolumn{2}{|c}{15356} \\
\hline
\end{tabular}

Table 5. Acquisition price: Gas (Source: compiled by the authors)

\begin{tabular}{l|c|c}
\hline \multicolumn{3}{c}{ Gas boiler } \\
\hline Component & amount & price $[€]$ \\
\hline Natural gas boiler & $1 \mathrm{pc}$ & 896 \\
\hline Chimney & $1 \mathrm{pc}$ & 1411 \\
\hline Floor heating distribution & $160 \mathrm{~m}^{2}$ & 6281 \\
\hline Gas fixture & $1 \mathrm{pc}$ & 1230 \\
\hline Total & \multicolumn{2}{|c}{9819} \\
\hline
\end{tabular}

Tariff prices were determined based on the heating system and distributors of electric energy and gas. The prices are typical for the Czech Republic. The tariff D45d is selected for electric heating foils and allows purchase of electric energy for a better price in comparison with the general tariff. The tariff D45d is designed for electric heaters. The tariff D55d, which is virtually identical to the tariff D45d, is designed for heat pumps. The manufacturer sets the seasonal coefficient of performance (SCOP) to 4.72 for heat pumps. Regarding the variant with a gas boiler, a tariff is selected with the price for a $\mathrm{kWh}$, which is approx. double in comparison with tariffs D45d and D55d. The tariff prices are shown in Table 6 .
Table 6. Selected tariffs, price per $1 \mathrm{kWh}$ (Source: compiled by the authors)

\begin{tabular}{l|l|l}
\hline \multicolumn{3}{c}{ Tariffs } \\
\hline Electricity D45d & 0.0810 & $€ / \mathrm{kW}$ \\
\hline Electricity D55d & 0.0811 & $€ / \mathrm{kW}$ \\
\hline Electricity standard & 0.1766 & $€ / \mathrm{kW}$ \\
\hline Gas & 0.0367 & $€ / \mathrm{kW}$ \\
\hline
\end{tabular}

The input data include the prices of supplied energy and heat losses of the building in question. The results of the analysis of the operating costs for heating are shown in Table 7.

Table 7. Operating costs for heating per year (Source: compiled by the authors)

\begin{tabular}{l|c|c|c}
\hline \multicolumn{4}{c}{ Operating costs [€/year] } \\
\hline & I. & II. & III. \\
\hline Electricity & 567 & 315 & 222 \\
\hline Heat pump Air/water & 120 & 67 & 47 \\
\hline Gas & 287 & 173 & 130 \\
\hline
\end{tabular}

\section{Evaluation}

The acquisition costs for heating per year are used in the calculation as the input data. The calculation takes into account some simplifications which have no significant impact on the evaluation (Ebel et al. 2014). A fixed price for energy is considered, the main components of the heating system are taken into account, and the heating factor SCOP for the whole year is considered for the heat pump (EHPA 2009). The overall evaluation also includes the above mentioned advantages and drawbacks of the heating systems. The evaluation deals with the comparison of the return rate of the acquisition price of heat pump and gas heating with electric heating foils, whose acquisition price is the lowest. Tables 8-12 show the outputs from the calculation of the return rate (Georges et al. 2010).

Table 8. Difference in acquisition prices of individual systems in comparison with electric heating foils (Source: compiled by the authors)

\begin{tabular}{l|c}
\hline \multicolumn{2}{c}{ Difference in acquisition prices [€] } \\
\hline Heat pump Air/Water & 12294 \\
\hline Gas & 6757 \\
\hline
\end{tabular}

To be more illustrative, the final values are shown in Fig. 1. The graph should be understood as follows: within the number of years (axis $\mathrm{x}$ ) the return rate of the surplus in acquisition costs is 
reached in comparison to electric heating foils (axis y). The graph shows the heating systems of heat pump air/water and gas in variants with AHU unit and without AHU unit, see Graph explanation (Audenaert et al. 2008).

Table 9. Difference in operating costs per year in comparison with electric heating foils (Source: compiled by the authors)

\begin{tabular}{l|c|c|c}
\hline \multicolumn{4}{c}{ Difference in operating costs $[€]$} \\
\hline & I. without AHU & II. with AHU & III. \\
\hline $\begin{array}{l}\text { Heat pump } \\
\text { Air/Water }\end{array}$ & 447 & 248 & 175 \\
\hline Gas & 281 & 143 & 91 \\
\hline
\end{tabular}

Table 10. Return rate of heating systems in comparison with electric heating foils (Source: compiled by the authors)

\begin{tabular}{l|c|c|c}
\hline \multicolumn{4}{|c}{ Return rate [Years] } \\
\hline & I. without AHU & II. with AHU & III. \\
\hline $\begin{array}{l}\text { Heat pump } \\
\text { Air/Water }\end{array}$ & 27 & 50 & 70 \\
\hline Gas & 24 & 47 & 74 \\
\hline
\end{tabular}

\section{Multi-criteria evaluation of heating systems}

When selecting a heating system, other criteria, not only the acquisition price and operating costs, play an important role, although these criteria do not have a crucial significance in the decision making process. The selection of a heating system is also influenced by the price of electricity and the number of low electricity tariff hours. The other potential criteria include emissions and the impact on the environment, the comfort of controlling, demands on the operation, system reliability, etc.

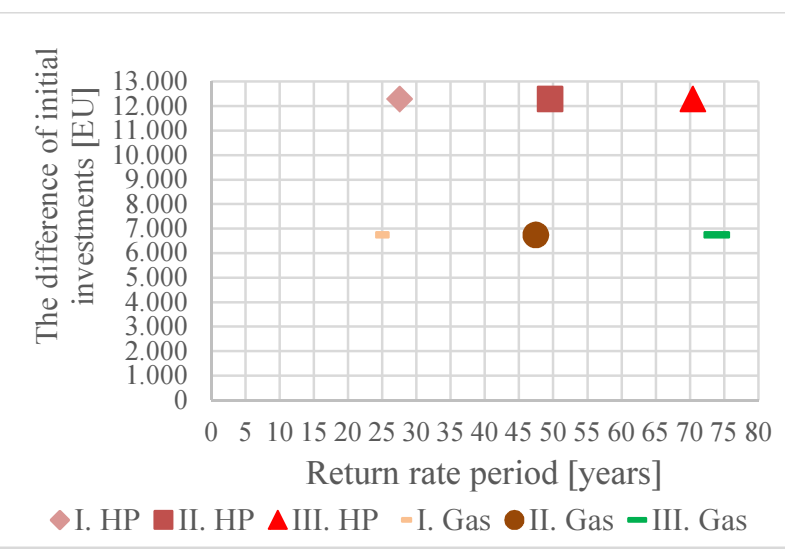

Fig. 1. Acquisition price return rate in comparison with electric floor heating (Source: compiled by the authors)

The decision-making situation, in which many criteria, often conflicting, must be respected, and the solution is not clear at first glance, is the subject of multi-criteria analysis (MCA).

The aim of the decision making process is to find the most useful type of a heating system for a given family house. The evaluation criteria are selected to provide more accurate evaluation of individual variants. Only the quantitative criteria were used.

The criteria have various dimensions, e.g. Euros, hours, etc. Some of them are maximizing the criteria, implying that the situation is better when the values of the criteria are increasing, e.g. number of low tariff hours. Other criteria are minimizing criteria, which means that the decreasing criteria values indicate a better situation, e.g. acquisition price. Therefore, all the criteria were examined and their values were transformed respectively. The multi-criteria evaluation methods may only be applied when normalized criteria values and weights are determined (Ginevičius et al. 2010).

Table 11. Input values of multi-criteria evaluation (Source: compiled by the authors)

\begin{tabular}{|c|c|c|c|c|c|c|}
\hline & & & & \multicolumn{3}{|c|}{ Heating systems (alternatives) } \\
\hline & & & & $a_{1}$ & $a_{2}$ & $\mathrm{a}_{3}$ \\
\hline$i$ & Criterion & $\begin{array}{l}\text { Type of } \\
\text { criterion }\end{array}$ & dimension & $\begin{array}{c}\text { Electric floor heating } \\
\text { ECOFILM }\end{array}$ & $\begin{array}{l}\text { Heat pump } \\
\text { air/water }\end{array}$ & $\begin{array}{c}\text { Gas condensing } \\
\text { boiler }\end{array}$ \\
\hline 1 & Acquisition price & $\min$ & $€$ & 3062 & 15356 & 9819 \\
\hline 2 & Operating costs (var. I) & $\min$ & $€ /$ year & 567 & 120 & 287 \\
\hline 3 & Prices for electricity & $\min$ & $€ / \mathrm{kW}$ & 0.08 & 0.08 & 0.18 \\
\hline 4 & $\begin{array}{l}\text { Number of hours Low } \\
\text { tariff }\end{array}$ & $\max$ & $\mathrm{h}$ & 20 & 22 & 0 \\
\hline
\end{tabular}


The default criterial matrix

$$
\begin{aligned}
& \begin{array}{llll}
i_{1} & i_{2} & i_{3} & i_{4}
\end{array} \\
& \min \min \min \max \\
& \begin{array}{l}
a_{1} \\
a_{2} \\
a_{3}
\end{array}\left[\begin{array}{cccc}
3062 & 567 & 0.08 & 20 \\
15356 & 120 & 0.08 & 22 \\
9819 & 287 & 0.18 & 0
\end{array}\right]
\end{aligned}
$$

was modified to the shape of all criteria maximizing, subtracting the criteria value of the options from the worst levels of minimizing criteria (Fiala et al. 1994). It was transferred to the ranking, by how much are variants better than the worst option, and thus on the maximizing criterion.

Adjusted criterion matrix then has the form

$$
\begin{aligned}
& \begin{array}{llll}
i_{1} & i_{2} & i_{3} & i_{4}
\end{array} \\
& \max \max \max \max \\
& \begin{array}{l}
a_{1} \\
a_{2} \\
a_{3}
\end{array}\left[\begin{array}{cccl}
12294 & 0 & 0.1 & 20 \\
0 & 447 & 0.1 & 22 \\
5537 & 280 & 0 & 0
\end{array}\right] .
\end{aligned}
$$

Each of the criterion from the selected set of criteria was assigned with a weight which determines its significance by the Ranking method.

This method is based on the ranking of criteria by preferences, while each criterion is assigned with bi points by the formula $b_{i}=m+1-i p$, where $\mathrm{m}$ is the number of criteria, ip $=(1, \cdots, m)$ and ip number of criteria pre-ordered by preferences (Doubravová 2009).

The weight of $\mathrm{i}$-th criterion is calculated by the formula (Brožová et al. 2003):

$$
\omega_{i}=\frac{b_{i}}{\sum_{i=1}^{m} b_{i}} .
$$

Table 12. The values of weight of i-th criterion (Source: compiled by the authors)

\begin{tabular}{c|l|c|c}
\hline$i$ & Criterion & $i_{p}$ & $\omega_{i}$ \\
\hline 1 & Acquisition price & 1 & 0.4 \\
\hline 2 & Operating costs (var. I) & 2 & 0.3 \\
\hline 3 & Price for electricity & 4 & 0.1 \\
\hline 4 & Number of hours Low tariff & 3 & 0.2 \\
\hline
\end{tabular}

In order to determine the ranking of convenience of individual heating systems, a method PROMETHEE (Preference Ranking Organisation Method for Enrichment Evaluation) was used.
The PROMETHEE I and PROMETHEE II methods were developed by Brans and presented for the first time in 1982 at a conference in Canada (Maity, Chakraborty 2015).

It is regarded as one of the most well-known outranking methods and has been widely applied to solve practical decision making problems. It includes five parts: (1) determine deviations based on pairwise comparisons of alternatives concerning each criterion; (2) construct a relevant preference function for each criterion; (3) calculate global preference index; (4) calculate positive and negative outranking flow of each alternative; and (5) calculate the net outranking flow of each alternative and determine a complete ranking of alternatives (Liu et al. 2016).

The results of evaluation by this method depend on the choice of the function of preferences for each criterion describing the researched building and the determination of their parameters (Fotr et al. 2003).

The methods PROMETHEE compare all the alternatives $\mathrm{Aj}$ and $\mathrm{Ak}$, calculating the outranking relationship $\pi(\mathrm{Aj}, \mathrm{Ak})$. In addition, an opposite operation of calculating the relationship between the alternative $\mathrm{Ak}$ and $\mathrm{Aj}, \pi(\mathrm{Ak}, \mathrm{Aj})$ is performed, usually, $\pi\left(A_{j}, A_{k}\right) \neq \pi\left(A_{k}, A_{j}\right)$ (Ginevičius et al. 2010).

The outranking relationship $\pi(\mathrm{Aj}, \mathrm{Ak})$ is gained by the formula (Montajabiha 2016):

$$
\pi\left(A_{j}, A_{k}\right)=\sum_{i=1}^{m} \omega_{i} p_{t}\left(d_{i}\left(A_{j}, A_{k}\right)\right),
$$

where $\omega_{i}$ is the weight of the $\mathrm{i}$-th criterion $\mathrm{Ri}$, $\sum_{i=1}^{n} \omega_{i}=1 ; \quad d_{i}\left(A_{j}, A_{k}\right)=r_{i j}-r_{i k}$ is the difference between the values $r_{i j}$ and $r_{i k}$ of i-th criterion Ri of alternatives $\mathrm{Aj}$ and $\mathrm{Ak} ; p_{t}(d)=p_{t}\left(d_{i}\left(A_{j}, A_{k}\right)\right)$ is the $t$-th preference function chosen for the i-th criterion (Ginevičius et al. 2010).

The Usual preference function was selected for all criteria

$$
p(d)=\left\{\begin{array}{l}
0, \text { when } d \leq 0 \\
1, \text { when } d>0
\end{array},(\text { Montajabiha 2015). }\right.
$$

The method PROMETHEE calculate the sums of all positive relationships of every $\mathrm{j}$-th alternative (Ginevičius et al. 2010):

$$
F_{j}^{+}=\sum_{k=1}^{n} \pi\left(A_{j}, A_{k}\right)
$$


and the sums of all negative relationships:

$$
F_{j}^{-}=\sum_{k=1}^{n} \pi\left(A_{k}, A_{j}\right),(j=1,2, \ldots, n) .
$$

Analysing the values $F_{j}^{+}$and $F_{j}^{-}$ $(j=1,2, \ldots, n)$, PROMETHEE I determines the best of the alternatives considered. PROMETHEE II calculates the differences between these relationships $F_{j}=F_{j}^{+}-F_{j}^{-}$and ranks the alternatives in the decreasing order of the differences between the values $F_{j}$ (Ginevičius et al. 2010).

The values of the outranking relationship $\pi\left(A_{j}, A_{k}\right)$, the sums of all positive ("outcoming") relationship $F_{j}^{+}$and negative ("incoming") relationships $F_{j}^{-}$, as well as the differences between them $F_{j}=F_{j}^{+}-F_{j}^{-}(j=1,2, \ldots, n)$ and the ranks of all ranked heating systems determined by using the method PROMETHEE II are given in Table 13.

Table 13. The results obtained in calculating convenience of heating system for family house by the method PROMETHEE (Source: compiled by the authors)

\begin{tabular}{c|c|c|c}
\hline \multirow{2}{*}{$\begin{array}{c}\text { Heating systems } \\
\text { (alternatives) }\end{array}$} & \multicolumn{3}{|c}{ Heating systems (alternatives) } \\
\cline { 2 - 4 } & $a_{1}$ & $a_{2}$ & $a_{3}$ \\
\hline $\mathrm{a}_{1}$ & 0 & 0.5 & 0.7 \\
\hline $\mathrm{a}_{2}$ & 0.5 & 0 & 0.6 \\
\hline $\mathrm{a}_{3}$ & 0.3 & 0.4 & 0 \\
\hline $\mathrm{F}^{+}$ & 1.2 & 1.1 & 0.7 \\
\hline $\mathrm{F}^{-}$ & 0.8 & 0.9 & 1.3 \\
\hline $\mathrm{F}$ & 0.4 & 0.2 & -0.6 \\
\hline rank & 1 & 2 & 3 \\
\hline
\end{tabular}

According to multi-criteria analysis results with the use of PROMETHEE method, the most convenient type of heating system for a given family house is variant 1 - electric floor heating ECOFILM. However, the selection of the optimum variant is a rather individual act, since it depends on the attitude of the person making a decision and his/her preferences. The greatest emphasis was put to the acquisition price, which is the lowest for the given system.

The impact of criteria $2-4$ had a positive effect particularly regarding the system with a heat pump, where it was evaluated as the second best, despite the high acquisition price. Only the variant I was evaluated, since the method is based on the mutual comparison of values of alternatives $\mathrm{Aj}$ and $\mathrm{Ak}$.
Having selected the function $p(d)$, the values of this function for variants I, II and III stay identical, therefore the evaluation of individual criteria for individual variants stays identical, too.

\section{Conclusions}

The system with electric heating foils is a very simple way of heating. The system has no mechanical parts, thus its life span is higher. The system can be installed in a very short time. The heating foils can be easily regulated and react quickly to immediate requirements. Another main advantage is the low acquisition price. One of the drawbacks is its impact on the environment, which depends on the energy mix in the given area where the energy is produced, how the energy is produced and with what efficiency.

The system with a heat pump air/water is a very popular heating system. The system has very low operating costs, but its acquisition costs are ranked among the highest. The heating system can be controlled easily and is virtually maintenance-free. However, it is necessary to take into account the life span of pumps, which generally reaches 10 years. In addition, it is necessary to consider where to use this system, since the effectiveness of the heat pump decreases with decreasing temperature of external air. A more favourable tariff of electric energy for the whole building is also an advantage.

Regarding the system with a gas boiler, it is necessary to take into account extra costs, such as costs for the gas fixture, gas inspection, and chimney. The system uses a non-renewable source very effectively; the effectiveness can reach even over $100 \%$ for condensing boilers. Gas can also be used for cooking. The drawbacks include a large number of mechanical parts, i.e. lower life span and need of regular inspections of the whole system together with the chimney.

The obtained results clearly show the mutual dependency of operating costs and acquisition prices of the systems on financial return rate. The lower heat loss of the building, the higher impact on the financial return rate in comparison with prices for energy. Therefore, it is more convenient to choose a cheaper heating system despite the higher price for energy. The convenience of a cheaper heating system grows with decreasing heat loss of the building. The decision on the choice of a heating system also depends on many other parameters which need to be taken into account.

These parameters include: simple operation, comfortable system of flexibility to react to immediate requirements, need to store fuel, reliability, 
system life span, and the impact on the environment. A multi-criteria analysis, which considered a large number of criteria, was performed. Based on the results of the method PROMETHEE, the electric floor heating ECOFILM was selected as the most convenient system. However, the conclusions of this method depend on the attitude and preferences of the person making a decision.

The option of a future research in this field could be the inclusion of water heating costs. The heating of water and the building itself is commonly ensured by just one heating system or by systems closely connected. The more complex survey of the efficiency and profitability of particular systems would be created. Another option is to include the use of renewable energy resources, either for the water heating or to support the building heating by the connectoin of photovoltaic or thermic systems. The use of these resources is becoming more and more efficient and popular with the building owners.

\section{Funding}

This contribution has been worked out under the project No. LO1408 "AdMaS UP - Advanced Materials, Structures and Technologies" supported by Ministry of Education, Youth and Sports under the "National Sustainability Programme I".

\section{References}

Audenaert, A.; De Cleyn, S. H.; Vankerckhove, B. 2008. Economic analysis of passive houses and lowenergy houses compared with standard houses, Energy Policy 36(1): 47-55. http://dx.doi.org/10.1016/j.enpol.2007.09.022

Bečkovský, D.; Kalábová, T.; Šuhajda, K.; Novotný, M.; Krupicová, J. 2012. Experimentální dřevostavba EXDR1, vydáno $v$ Materiály pro stavbu [Experimental timber house EXD1 contribution in Materials for construction], Business Media CZ, s.r.o., Praha 5, Praha. ISSN 1213-0311 (in Czech).

Brožová, H.; Houška, M.; Šubrt, T. 2003. Modely pro vícekriteriální rozhodování [Models for multicriteria decision]. Praha: Credit. 178 p. ISBN 80213-1019-7 (in Czech).

ČSN 73 4301. Obytné budovy [Residential buildings]. 6.2004. UNMZ cz, 2004 (in Czech).

ČSN 73 0540-1. Tepelná ochrana budov - Část 1: Terminologie [Thermal protection of buildings Part 1: Terminology]. 6.2005. UNMZ cz, 2005 (in Czech).

ČSN 73 0540-2. Tepelná ochrana budov - Část 2: Požadavky [Thermal protection of buildings -
Part 2: Requirements]. 10.2011. UNMZ cz, 2011 (in Czech).

ČSN 73 0540-3. Tepelná ochrana budov - Část 3: Návrhové hodnoty veličin [Thermal protection of buildings - Part 3: Design value quantitles]. 11.2005. UNMZ cz, 2005 (in Czech).

ČSN 73 0540-4. Tepelná ochrana budov - Část 4: Výpočtové metody [Thermal protection of buildings - Part 4: Calculation methods]. 6.2005. UNMZ cz, 2005 (in Czech).

Debacker, W.; Allacker, K.; Spirinckx, C.; Geerken, T.; Troyer, F. 2013. Identification of environmental and financial cost efficient heating and ventilation services for a typical residential building in Belgium, Journal of Cleaner Production 57: 188199. http://dx.doi.org/10.1016/j.jclepro.2013.05.037

Doubravová, H. 2009. Vicekriteriální analýza variant a její aplikace $v$ praxi, diplomová práce [Multicriterial analysis and its application in practice, diploma thesis] [online]. Jihočeská univerzita $\mathrm{v}$ Českých Budějovicích, Ekonomická fakulta. České Budějovice [cited 20 December 2015]. Available from Internet:

http://theses.cz/id/6citbe/downloadPraceContent_a dipIdno_11361

Ebel, W.; Feist, W.; Kaufmann, B. 2014. Economy and financing of efficiency: new buildings, renovation and step by step retrofit, in $18^{\text {th }}$ International Passive House Conference, 2014, Darmstadt, Germany. ISBN 978-3-00-045216-1.

EHPA. 2009. European heat pump statistics: outlook 2009. The European Heat Pump Association, Brussels.

Feist, W. 2013. PHPP - software for designing passive houses: version 8 (2013). Passive House Institute, Darmstadt, Germany.

Fenix. 2015. ECOFILM F-folie pro podlahové vytápění [ECOFILM F - floor heating foils] [online]. Fenixgroup [cited 08 November 2015]. Available from Internet: www.fenixgroup.cz

Fiala, P.; Jablonský, J.; Maňas, M. 1994. Vicekriteriální rozhodování: Určeno pro stud. všech fak [Multicriteria decision: Designed for studies in all faculties]. 1. vyd. Praha: Vysoká škola ekonomická. 316 p. ISBN 80-7079-748-7

Fotr, J.; Dědina, J.; Hrůzová, H. 2003. Manažerské rozhodování. Praha: Ekopress. 250 p. ISBN 8086119-69-6

Georges, L.; Massart, C.; Van Moeseke, G.; De Herde, A. 2010. Environmental and economic performance of heating systems for energy-efficient dwellings: case of passive and low-energy single-family houses, Energy Policy 40: 452-464. http://dx.doi.org/10.1016/j.enpol.2011.10.037

Ginevičius, R.; Podvesko, V.; Novotny, M. 2010. Evaluating Lithuanian banks from the perspective of their reliability to customers by Promethee 
method, in $6^{\text {th }}$ International Scientific Conference Business and Management, 13-14 May 2010, Vilnius, Lithuania. 993-999. ISSN 2029-4441.

Hirvonen, J.; Kayo, G.; Hasan, A.; Sirén, K. 2016. Zero energy level and economic potential of small-scale building-integrated PV with different heating systems in Nordic condition, Applied Energy 167: 255-269.

http://dx.doi.org/10.1016/j.apenergy.2015.12.037

Kazanci, O.; Shukuya, M.; Olesen, B. 2016. Exergy performance of different space heating systems: a theoretical study, Building and Environment 99: 119-129.

http://dx.doi.org/10.1016/j.buildenv.2016.01.025

Kolb, J. 2011. Dřevostavby: systémy nosných konstrukcí, obvodové pláště [Timber houses: bearing structures systems, building envelopes]. 2, aktualiz. vyd. v České republice. Praha: Grada. 317 p. ISBN 97880-247-4071-3 (in Czech).

Kulhánek, F. 2010. Nízkoenergetické a pasivní domy: návrh a realizace: elektronická příručka [Low energy and passive houses: design and implementtation: electronic manual]. Praha: Dashöfer. ISSN 1804-736x. (in Czech)

Liu, Y.; Fan, Z.; Zhang, X. 2016. A method for large group decision-making based on evaluation information provided by participators from multiple groups, Information Fusion 29: 132-141.

http://dx.doi.org/10.1016/j.inffus.2015.08.002
Najbrt, T.; Lenoch, J. 2012. Ekonomické hodnocení užívání dřevostavby pro různé varianty vytápění [Economical evaluation of the timber houses in use for different variants of heating systems], Dřevostavyby [Timber Houses conference]. Vyšší odborná škola a Střední průmyslová škola, Volyně, Czech Republic, 92-95. ISBN 978-80-86837-36-9

Maity, S.; Chakraborty, S. 2015. Tool steel material selection using PROMETHEE II method, The International Journal of Advanced Manufacturing Technology 78(9): 1537-1547. http://dx.doi.org/10.1007/s00170-014-6760-0

Montajabiha, M. 2016. An extended PROMETHEE II multi-criteria group decision making technique based on intuitionistic fuzzy logic for sustainable energy planning, Group Decision Negotiation 25: 221-244. http://dx.doi.org/10.1007/s10726-015-9440-z

Rajagopalan, P.; Leung, T. C. Y. 2012. Progress on building energy labelling techniques, Advances in Building Energy Research 6(1): 61-80. http://dx.doi.org/10.1080/17512549.2012.672002

Yildiz, A.; Güngör, A. 2009. Energy and exergy analyses of space heating in buildings, Applied Energy 86(10): 1939-1948.

http://dx.doi.org/10.1016/j.apenergy.2008.12.010 